\title{
Deep Learning as Constructed in Mathematics Teachers' Written Discourses
}

\author{
Janne Fauskanger ${ }^{1 *}$, Raymond Bjuland ${ }^{1}$ \\ ${ }^{1}$ Department of Education and Sports Science, University of Stavanger, Stavanger, NORWAY \\ *CORRESPONDENCE: \janne.fauskanger@uis.no
}

\begin{abstract}
This study explores the notion of deep learning as constructed in the discourses of practicing mathematics teachers. Analyses of data from written texts show that the teachers tend to conceptualise deep learning in terms of two broad categories: students' deep learning and the work of teaching for deep learning. In both categories, students' previous knowledge or background knowledge, students' thinking and their understanding, interdisciplinarity and relations to daily life are emphasised. Related to the work of mathematics teaching for deep learning, variation in mediating tools, variation in approaches to teaching, the learning objective for a lesson and the importance of applying knowledge are emphasised. Possible implications from these findings are discussed.
\end{abstract}

Keywords: deep learning, mathematics teachers' discourse, teachers' views

\section{INTRODUCTION}

The question of what constitutes deep learning in teaching has recently been paid considerable attention to in educational research (e.g. Rillero, 2016). This has also been the case in Norway, in which national steering documents have emphasised the close connection between competence and deep learning. In a recent steering document, the concept of deep learning is explained in the following way:

\begin{abstract}
Deep learning means that students gradually develop their understanding of concepts, systems of concepts, methods and connections within a subject area. It also deals with understanding topics/themes and approaching problems across subject areas or areas of knowledge. Deep learning implies that students use their ability to analyse, to solve problems and reflect about own learning in order to construct an understanding to their own lives (NOU 2015:8, p. 14, our translation).
\end{abstract}

Rillero (2016) has found that research confirms that deep learning and surface learning represent two completely different styles of learning. Deep learners are more likely to think and discuss by seeking to understand concepts and to apply the concepts "to real life situations, or question conclusions", while surface learning is "marked by memorization, rote learning, and unquestioning acceptance of information" (Rillero, 2016, p. 16). This researcher claims that most of the research on deep learning versus surface learning has been conducted in higher education. The aim of this study is thus, to investigate elementary school mathematics teachers' views about deep learning. There are many ways to denote the way teachers talk or write about deep learning. The approach chosen for this article is to study mathematics teachers' views about deep learning through analysis of their written texts. These texts are seen as parts of their discourses on deep learning. In the present study, we analyse the texts with a focus on how teachers construct the notion of deep learning in their written discourses. Our approach to analyse data draws upon the study by Hemmi and Ryve

\footnotetext{
Article History: Received 23 March $2018 \bullet$ Revised 21 June $2018 \bullet$ Accepted 4 July 2018

(C) 2018 The Author(s). Open Access terms of the Creative Commons Attribution 4.0 International License (http://creativecommons.org/licenses/by/4.0/) apply. The license permits unrestricted use, distribution, and reproduction in any medium, on the condition that users give exact credit to the original author(s) and the source, provide a link to the Creative Commons license, and indicate if they made any changes.
} 
(2015). Where these researchers focused on teacher educators, we focus on practicing teachers and where they study how Finnish and Swedish teacher educators conceptualise effective mathematics teaching, we study how Norwegian mathematics teachers conceptualise deep learning. We address the following research questions: What aspects of deep learning constitute a group of Norwegian mathematics teachers' written discourses? What challenges and what "success stories" related to teaching promoting deep learning do the teachers' written discourses reveal? To answer these questions, we analyse texts written by teachers before a collaborative research and development project started (see methodology section for details about the project). To our knowledge, few studies have examined (Norwegian) teachers' construction of deep learning from studying their written discourses.

\section{DEEP LEARNING IN THE EXISTING LITERATURE}

Research into deep learning can be traced back to the mid 1970s in Sweden when Ference Marton and colleagues investigated Swedish university students who were asked to read academic articles within suggested time limit followed by being asked specific questions about substantial passages from the articles (Marton, 1975; Marton \& Säljö, 1976). Findings from recorded conversations with the university students revealed two qualitative differences in the learning outcome. Some students tried to understand the substantial passages of prose from the articles by grasping and comprehending what they were reading, and they tried to relate the content to previous knowledge. Another completely different style of learning could be identified when university students tried to memorise particular aspects in the articles. Marton and Säljö (1976, p. 14, italics in original) have described these qualitative differences in the levels of learning "in terms of whether the learner is engaged in surface-level or deep-level processing." A surface approach to learning thus involves minimum engagement with e.g. a task, typically with a focus on memorisation or applying procedures that do not involve reflection or understanding. In contrast, a deep approach to learning involves e.g. a focus on relationships between various aspects of the content, with an intention to understand and impose meaning.

From these beginning texts about deep learning, the development of the new science of learning has been introduced to a broad audience by e.g. handbooks, providing an in depth overview over deep learning versus surface learning and how to use deep learning to design effective learning environments in classrooms across subject areas. In the handbook, "How People Learn" (Bransford, Brown, \& Cocking, 2000/2004, p. 8), the authors state that one of the hallmarks of what they call "the new science of learning" is the emphasis on learning with understanding used parallel to deep learning. Still, students must have a deep foundation in factual knowledge since knowing facts are important to memorise for thinking and problem solving, but new knowledge must be constructed from pre-existing knowledge and learners must be encouraged to be active and take control of their own learning (Bransford et al., 2000/2004). These authors challenge the view that memorisation equals surface learning, and they suggest that deep learning of subject matter helps learners to draw on factual information and transform it to usable knowledge in a problem-solving context by generating arguments and explanations and drawing analogies to other problems.

In mathematics education, the discussion on procedural understanding and conceptual understanding has deep roots (e.g. Hiebert \& Lefevre, 1986; Star, 2005), and for many decades terms such as 'rote learning' and 'real understanding' have coloured the debate on learning (Schoenfeld, 2007). In this context, 'rote learning' is often used parallel to the memorising of facts or procedures thus to surface learning. 'Rote learning' is also used parallel to terms such as procedural knowledge or procedural understanding (Hiebert \& Carpenter, 1992; Hiebert \& Lefevre, 1986), and to instrumental understanding (cf. Skemp, 1976). 'Real understanding' is often used parallel to deep learning and terms such as relational understanding (Skemp, 1976) and conceptual understanding (Hiebert \& Carpenter, 1992; Hiebert \& Lefevre, 1986). However, more elaborated distinctions exist (e.g. de Jong \& Ferguson-Hessler, 1996). These researchers claim that a person's knowledge base is made out of different types of knowledge such as conceptual and procedural knowledge and that this knowledge base can be characterised by qualities such as deep or surface levels of knowledge. A focus on deep learning will according to de Jong and Ferguson-Hessler (1996), be on qualities of teachers' knowledge.

Equal to Bransford et al. (2000/2004) and de Jong and Ferguson-Hessler (1996) in the general education context, the dichotomy between 'rote learning' and 'real understanding' (Schoenfeld, 2007) is also challenged in the context of mathematics education. One example is Leung (2001) who distinguishes the dichotomy rote learning versus deep learning by saying that classifying memorisation "as rote learning without understanding is too simplistic a view" (Leung, 2001, p. 41). Memorisation and understanding are seen as working together to produce higher quality outcomes (cf. Marton, Dall'Alba, \& Tse, 1996). The connection 
between memorisation and understanding relates to meaningful repetition (Dahlin \& Watkins, 2000), which can lead to memorisation as well as understanding (Li, 1999). Procedural understanding is thus, not parallel to surface learning because procedural learning can be with understanding (i.e. relational, cf. Skemp, 1976). This is also visible when Star (2005) reconceptualises procedural understanding. With reference to de Jong and Ferguson-Hessler (1996), Star (2005) relates the concepts deep and superficial knowledge to procedural as well as to conceptual understanding.

Byrne, Flood and Willis (2004) also challenge the dichotomy deep learning and surface learning, but from a somewhat different perspective than as an example Star (2005). In their factor analysis on data gathered from a sample of students in the USA and Ireland, they found that the resulting factor patterns clearly identified deep and surface approaches to learning as well as a third factor: strategic learning which will however, not be the focus of attention in this article.

Even if the dichotomy deep learning and surface learning is challenged and developing conceptual understanding and procedural fluency is seen as an iterative process (Rittle-Johnson, Siegler, \& Alibali, 2001), the discussion in the field of mathematics education is ongoing (see e.g. Fan \& Bokhove, 2014; Rittle-Johnson $\&$ Stiegler, 1998). Deep learning and surface learning as extremes are however, often used in the literature to point at specific issues (see Table 1). Building on the handbook, "How People Learn" (Bransford et al., 2000/2004), a second handbook ("The Cambridge Handbook of the Learning Sciences", Sawyer, 2014) has summarised important characterisations of deep learning versus surface learning presented as the extremes visible in Table 1.

Table 1. Learning knowledge deeply versus surface learning (adapted from Sawyer, 2014, p. 4) Deep learning Surface learning

Deep learning requires that students* relate new ideas Students treat course material as unrelated to and concepts to previous knowledge and experience. what they already know.

Deep learning requires that students integrate their Students treat course material as disconnected knowledge into interrelated conceptual systems. $\quad$ bits of knowledge.

Deep learning requires that students look for patterns $\quad$ Students memorize facts and carry out procedures and underlying principles.

Deep learning requires that students evaluate new ideas, and relate them to conclusions. without understanding how or why. Students have difficulty making sense of new ideas that are different from what they encountered in the textbook.

Deep learning requires that students understand the Students treat facts and procedures as static process of dialogue through which knowledge is created, knowledge, handed down from an all-knowing and they examine the logic of an argument critically. authority.

Deep learning requires that students reflect on their own Students memorize without reflecting on the understanding and their own process of learning. purpose or on their own learning strategies.

*"learners" is used by Sawyer (2014)

In the study presented in this article, the teachers were asked to describe their understanding of deep learning versus surface learning in relation to a chosen theme (see methodology section). Based on this, extremes such as those presented in the first and second column in Table 1, might be expected to be visible in the mathematics teachers' written discourses.

\section{Teaching Promoting Students' Deep Learning}

From research on learning sciences, Sawyer (2014, p. 4) emphasises that one of the central underlying themes is that "students learn deeper knowledge when they engage in activities that are similar to the everyday activities of professionals who work in a discipline." This relates to teaching that promotes deep learning. The focus on teaching is also visible in the quote from the steering document presented in the introduction: "Deep learning implies that students use their ability to analyse, to solve problem and reflect about own learning in order to construct an understanding to their own lives" (NOU 2015:8, p. 14, our translation). When studying how "new pedagogies find deep learning", Fullan and Langworthy (2014) highlight that forces converging to produce deep learning outcomes are as an example (new) learning based in the real world of action and problem solving. They have from their research found that in the best teaching examples, teachers and students are working together in order to engage students in the learning by relating the learning to real-life problem solving. When engaging in deep learning, teachers and students partner with each other in learning processes where "high expectations are mutually negotiated and achieved through challenging deep learning tasks" (Fullan \& Langworthy, 2014, p. ii). Higher levels of student achievement and 
the capacity to apply what one knows relate to what Fullan (2013) characterises as important Cs such as communication, collaboration and critical thinking and problem solving. These are defined as follows:

Communication - communicate effectively orally, in writing and with a variety of digital tools;
listening skills,

Collaboration - work in teams, learn from and contribute to the learning of others, social networking skills, empathy in working with diverse others,

Critical thinking and problem solving - think critically to design and manage projects, solve problems, make effective decisions using a variety of digital tools and resources (Fullan, 2013, p. 9).

Teaching promoting deeper learning is also visible in early texts from mathematics education. One example is Skemp (1976). When discussing the terms relational understanding and instrumental understanding in a teaching context, he highlights advantages for teaching both approaches. Teaching for understanding mathematics instrumentally is often easier because some topics can be difficult to explain relationally (e.g. multiplying two negative numbers). It is also easier for students to get correct answers, suggesting that the rewards are more immediate, and "one can often get the right answer more quickly and reliably by instrumental thinking than relational" (Skemp, 1976, p. 158). In order for the students to understand mathematics relationally, Skemp emphasises that teaching for relational understanding is more adaptable to new situations for instance by relating a problem to another one. A second advantage is that formulas and rules are easier to remember when they are considered as interrelated and parts of a connected whole. Skemp (1976) also states that relational understanding can be a reward in itself without a need for external rewards.

As in the quote from the steering document presented in the introduction (NOU 2015:8, p. 14), problem solving is often seen as the mean for reaching the goal deep learning (cf. the "challenging deep learning tasks" put forward by Fullan and Langworthy (2014, p. ii)). In mathematics education, there is a long history of using inquiry approaches and problem solving in classrooms, giving students opportunities to explore mathematical problems (Bjuland \& Jaworski, 2009). Based on extensive literature in the field, these authors claim that inquiry-based problem solving is important in order to seek "for knowledge and understanding, both in mathematics and in processes of learning and teaching mathematics” (Bjuland \& Jaworski, 2009, p. 22).

In line with Bjuland and Jaworski (2009) and building on research on students' deep learning, recent research concludes that cognitive types of teacher knowledge matter in order for students to learn deeply: Teachers' knowledge of facts and procedures has a relatively smaller positive effect on students' achievement than teachers' knowledge of concepts and connections (Tchoshanov, 2011). In addition to teacher knowledge, teaching practices enhancing students' deep learning of complex ideas and performances are crucial for the work of teaching for deep learning. These practices are often referred to as ambitious (e.g. Lampert, Beasley, Ghousseini, Kazemi, \& Franke, 2010). How these practices are used in instructional dialogue is the centerpiece of ambitious teaching practices and as a reason, ambitious teaching practices relate to Bransford et al.'s (2000/2004) statement that lessons need to be learner centered, knowledge centered, assessment centered, and community centered.

A recent study based on survey results from questionnaire items concerning mathematics and science education shows that many of the respondents believe that deep learning is very important for preparing students for future careers (Rillero, 2016). For the open-ended question about benefits of deep learning reported by teachers $(n=294)$, the most common response cluster was that students are "more effective thinkers in a variety of contexts" (Rillero, 2016, p. 20). One specific teacher response illustrates this by the following written discourse: "They develop thinking skills that go beyond looking answers up out of the book. Those thinking skills can be transferred to all aspects of their lives" (p. 20). In the questionnaire, the teachers were also asked to describe challenges of enacting deep learning. The most frequent category reported was related to the issue of time, including student learning and teacher planning $(n=96,33 \%)$. The second most frequent category reported was student attitude or behavior towards learning $(n=67,23 \%)$.

Based on this, it is important to investigate elementary school teachers' views about deep learning, in particular as a point of departure for a research and development project focusing on teaching providing students with the opportunity to learn deeper (see methodology section). As can be seen, several concepts are used in the literature in order to capture 'deep learning' as a process as well as a product. In this article, we investigate how Norwegian elementary school teachers approach or define this concept from their written discourses. 


\section{METHODOLOGY}

The study presented here is part of a larger research and development project entitled 'Didactic knowledge for teaching and learning in English, mathematics, and physical education.' In this project, teacher educators/researchers $(n=13)$ and all teachers $(n=40)$ and leaders $(n=3)$ at an elementary school (grades 1 to 7, 6-12 years) work together in order to develop teaching inviting students to develop "deeper knowledge" (Sawyer, 2014, p. 4). The project leaders had their first meeting in June 2017, and the first workshop including all participants was held in September 2017. Before this first workshop, i.e. before any concepts were discussed, all teachers were invited to provide written responses to the following:

- Choose one of the subjects mathematics, Norwegian, English, social sciences, natural sciences or religion. Think of the theme your class is working on right now (e.g. multiplication of fractions in mathematics or pronouns in English), and describe your understanding of deep learning versus surface learning in relation to this theme.

- Describe what you succeed in when (planning/carrying out) teaching which promotes students' deep learning.

- Describe what you find challenging, if your teaching (planning/carrying out) should promote students' deep learning.

The questions were given to the teachers electronically without further information. They were informed that their texts were going to be analysed from a research perspective, and they could use as much time as they wanted without any word limit.

In the part of the project presented here, 33 teachers participate (i.e. the teachers who provided written responses). They teach first to seventh grade at the same school. The teachers' teaching experience varies from 1 to 29 years. In this study however, the focus is not on differences in teaching experience and is therefore not reported on here. The overall design and selected population makes it possible to draw conclusions in relation to these teachers only and we cannot make any claims about the Norwegian teacher population in general.

For the purpose of this article, the written texts of the mathematics teachers (11 of 33 responses) were analysed by using content analysis (Fauskanger \& Mosvold, 2014; Hsieh \& Shannon, 2005). Two researchers (authors of this article) coded all the data material from these eleven teachers, named teacher A, B, C, D, E, $\mathrm{F}, \mathrm{G}+\mathrm{H}, \mathrm{I}, \mathrm{J}, \mathrm{K}$ (teacher $\mathrm{G}$ and $\mathrm{H}$ provided a common written response) independently and both researchers developed individual codes and grouped them into categories, in an iterative process including several cycles of analysis. The two researchers then reconciled and agreed upon categories and corresponding codes. Some minor adjustments to the codes were made during this process, but the categories listed remained the same (see Table 2, first row). In this process, our analysis made visible that in the mathematics teachers' texts, there were two main discourses. The first focusing on students' deep learning for "deeper knowledge" (Sawyer, 2014, p. 4), and the second focusing on the work of teaching for deep learning. As a result, we dug deeper into the data in order to identify aspects related to students' deep learning and to the teachers' work of teaching for deep learning in the teachers' written discourses. This process of analysis led to an identification of the codes and categories as presented in Table 2.

Analyses of the teachers' written descriptions of what they succeed in when planning and carrying out teaching promoting students' deep learning and on what they find challenging if their teaching should promote students' deep learning, also resulted in codes and categories (e.g. as presented in Table 2). Results from the analyses are presented and discussed, but tables presenting categories and examples are not presented due to limited space. 
Table 2. Categories, codes and example extracts from the mathematics teachers' texts Categories:

\begin{tabular}{lll}
\hline $\begin{array}{l}\text { Codes: } \\
\text { (number of teachers) }\end{array}$ & $\begin{array}{l}\text { The work of teaching for deep } \\
\text { learning }\end{array}$ & The students' deep learning \\
\hline Previous & We ground our work in [students'] & In [our] work on negative numbers, it is
\end{tabular}

knowledge/background knowledge (10)

\section{Students' thinking (their} strategies, dialogues and misconceptions) (7) We ground our work in [students'] In [our] work on negative numbers, it is previous knowledge and [we] pick up important that the students understand previous knowledge at the start of the positive numbers well. (teacher A) work with a theme. (teacher A)

Practical work, student-student talk, It is important that the students can student-teacher talk. (teacher J) explore their own strategies in order to discard those who do not work and conclude [to use] those who work. (teacher A)

Students' relational With a good understanding of the understanding signs [related to an equation] and (understanding connections, hopefully a collective understanding concept understanding) (3) that an equation can be rearranged in several ways - if only one messes up the relation between the left and righ side of the equality sign. It is not like 'plus becomes minus', but we can use all arithmetical operations - if only we do the same things on both sides of the equality sign. (teachers $\mathrm{G}+\mathrm{H}$ )

Interdisciplinarity/relations By deep learning I think that one [the to daily life (6) teacher] can bring in several subjects and [that one can] connect the theme to [students'] daily life in order to make it [the theme] more known [for the students]. (teacher $\mathrm{C}$ )
In the classroom conversations, the students get to know new concepts which they relate to their previous knowledge. They will then internalize the new concepts for further work. (teacher A)

It [deep learning] is also about understanding themes and problems across fields of knowledge. Related to this mathematical theme [More than 1000 and less than 0] deep learning is about relating this knowledge to daily life situations. (teacher B)

\footnotetext{
Variation in mediation tools [In our teaching we d]raw, visualise (textbook, number line, and use hands on materials. (teacher hands on materials, etc.) (7) E)

$\begin{array}{ll}\text { Variation in approaches to } & \text { [W] e use different strategies in our } \\ \text { teaching (8) } & \text { approach [to teaching]. Station work }\end{array}$ teaching (8) approach [to teaching]. Station work, teaching from the blackboard, the students participate actively in doings, visually to see a movie, auditive [to listen to] songs and music etc. (teacher $\mathrm{K}$ )

Learning goal for the lesson [We as teachers p]ractice to describe (2) orally the learning goal, what we are supposed to learn about. (teacher K)

'Apply knowledge' (2) [We as teachers u]se multiplication in practical situations, in other subjects where it is natural to use it [multiplication]. (teacher E)
}

\section{RESULTS AND DISCUSSION}

\section{Conceptualising Deep Learning}

Our analysis of the teachers' written texts reveals that the group of Norwegian mathematics teachers tend to conceptualise deep learning in terms of two broad categories: students' deep learning (e.g. Sawyer, 2014, Table 1) and the work of teaching for deep learning (e.g. Fullan \& Langworthy, 2014). In both categories students' background knowledge, students' thinking and their (relational, cf. Skemp, 1976) understanding, interdisciplinarity and relations to daily life are highlighted. Related to the work of teaching for deep learning, 
variation in mediating tools, variation in approaches to teaching, the learning objective for a lesson and the importance of applying knowledge are emphasised (see Table 2).

When describing their understanding of deep learning in relation to a chosen mathematical theme, ten out of the eleven teachers highlight students' previous knowledge or background knowledge as important for making deep learning possible. The focus on background knowledge is exemplified by the following extract from teacher A's text: "We ground our work in [students'] previous knowledge and [we] pick up previous knowledge at the start of the work with a theme." In line with this response, the ten teachers emphasise the importance of grounding their work of teaching on students' previous knowledge by picking "up previous knowledge at the start of the work with a theme." (teacher A). The teachers also focused on background knowledge as important for the students' development of deep understanding: "In [our] work on negative numbers, it is important that the students understand positive numbers well" (teacher A). In line with e.g. Sawyer (2014) and Bransford et al. (2000/2004), the ten teachers highlight that deep learning requires that students relate new ideas and concepts to previous knowledge and that students gradually develop their understanding of concepts (cf. NOU 2015:8).

A second theme visible in seven out of the eleven teachers' written discourses on deep learning is the importance of placing emphasis on students' thinking. As an example, teacher A writes that it is important "that the students can explore their own strategies in order to discard those who do not work and conclude [to use] those who work." This focus on students' thinking is important in a problem-solving context, giving students the opportunities to seek for knowledge and understanding of their own strategies (Bjuland \& Jaworski, 2009; Schoenfeld, 2007). This theme also relates to Sawyer (2014, p. 4) who emphasises that deep learning "requires that students reflect on their own understanding and their own process of learning." Also in NOU 2015:8 students' reflections about their own thinking and learning is highlighted related to deep learning. However, in our data material we do not see signs of discourses on "critical thinking", in which Fullan (2013, p. 9) states as important for high levels of student achievement. In order to place emphasis on students' thinking in their teaching, the seven teachers highlight dialogues and practical work as important in order to make it possible for students to reflect on their own thinking: "Practical work, student-student talk, studentteacher talk" (teacher J). These aspects, and in particular communication and collaboration, are highlighted by e.g. Fullan (2013) and Fullan and Langworthy (2014). However, to "communicate effectively" (Fullan, 2013, p. 9) is not elaborated on in the teachers' written discourses and talking to someone does not necessarily lead to deep learning; it depends on what they are talking about.

Closely related to the second theme, students' relational understanding - defined by the teachers as understanding concepts and connections (e.g. between concepts, cf. Skemp, 1976) - is put forward in the texts written by three teachers. As an example, teacher A emphasises the potential of discussing mathematical concepts in classroom conversations since "the students get to know new concepts which they relate to their previous knowledge. They will then internalise the new concepts for further work." The work of teaching for deep learning is highlighted by the two collaborative teachers $(\mathrm{G}+\mathrm{H})$ which are concerned with a "good understanding of the equality sign" in an equation, emphasising the importance of:

not to mess up the relation between the left and right side of the equality sign. It is not like 'plus becomes minus', but we can use all arithmetical operations - if only we do the same things on both sides of the equality sign.

These teachers confirm the importance of approaching new mathematical concepts with relational understanding (cf. Skemp, 1976) in a classroom learning environment that promotes learning outcomes which are learner centered and knowledge centered (cf. Bransford et al., 2000/2004).

The fourth theme, and the last focusing on the work of teaching for deep learning as well as students' deep learning is interdisciplinarity and/or relations to daily life. This theme is visible in six teachers' written discourses. When teacher $\mathrm{C}$ writes that " $[\mathrm{b}] \mathrm{y}$ deep learning I think that one [the teacher] can bring in several subjects and [that one can] connect the theme to [students'] daily life in order to make it [the theme] more known [for the students]", it is visible that the teacher relates the work of teaching for deep learning to students' daily life. When teaching for deep learning, the teacher is responsible for interdisciplinarity and/or relations to daily life. In the following extract from the text written by teacher B, interdisciplinarity and/or relations to daily life are also highlighted as important for students' deep learning: "It [deep learning] is also about understanding themes and problems across fields of knowledge. Related to this mathematical theme ["More than 1000 and less than 0"] deep learning is about relating this knowledge to daily life situations." In NOU (2015:8, p. 14), it is also emphasised that deep learning deals with understanding themes "across subject 
areas or areas of knowledge." The same is true for Rillero (2016), who found that deep learners are more likely to seek to understand concepts and to relate the concepts to daily life situations. Finally, Fullan and Langworthy (2014) highlight the capacity to apply knowledge. However, these researchers focus on real-life problem solving which does not emerge obviously from the analyses of our data material.

The focus of attention in the four last themes identified in our analyses of the teachers' written discourses is the work of teaching for deep learning only. The emphasis on the work of teaching is obvious since the discourses analysed are teachers' own written texts. The themes are however, interesting. Seven teachers put forward the importance of variation in mediating tools (e.g. textbook, number line, hands on materials, etc.). As an example, teacher $\mathrm{E}$ writes that teaching promoting students' deep learning needs to invite the students to "[d]raw, visualise and use hands on materials." Eight teachers emphasise variation in approaches to teaching as a premise for students' deep learning. As an example, teacher $\mathrm{K}$ writes: "[W]e use different strategies in our approach [to teaching]. Station work, learning/elbow partner, the teacher is teaching from the blackboard, the students participate actively in doings, visually to see a movie, auditive [to listen to] songs and music etc." In these eight teachers' texts, variation in approaches to teaching seem to relate to Bransford et al.'s (2000/2004) attributes of a classroom learning environment that promotes (deep) learning outcomes, e.g. that the lessons must be learner centered. However, if e.g. using an "elbow partner" (teacher K) should lead to deep learning, it will be dependent of what the partners are talking about. This is not elaborated on in the teachers' texts.

Two teachers highlight the importance for the teacher as well as for the students to know the learning goal for a given mathematics lesson. One of the two teachers (teacher $\mathrm{K}$ ) writes that it is important for teachers to: "Practice to describe orally the learning goal, what we are supposed to learn about." The goal for a given lesson relates lessons being knowledge centered (cf. Bransford et al., 2000/2004). The last aspect visible in two out of the 11 teachers' written discourses, is the importance of valuing application of knowledge in the work of teaching for deep learning (cf. Fullan \& Langworthy, 2014). One out of the two teachers is highlighting application of knowledge, exemplified by teacher $\mathrm{E}$ who writes that in the lessons it is important for teachers to: "[u]se multiplication in practical situations, in other subjects where it is natural to use it [multiplication]." From the last part of this extract, it is clear that application of mathematics (multiplication) in other subject areas is seen as important for students' learning more deeply from mathematics lessons. The ability to apply knowledge is also seen as a sign of students' deeper knowledge, as in the text written by teacher D: "In deep learning, the student manages to use the knowledge he/she has in new contexts. [...] The student has basic knowledge that makes it possible for him/her to apply the knowledge in new ways." Application of mathematics as important for students' deeper learning is visible in the teachers' discourses also in the following example extract from the text written by teacher D:

\begin{abstract}
In relation to deep learning, the student manages to apply his/her knowledge in new contexts. [...] The student does have basic knowledge making it possible for him/her to apply the knowledge in new ways. As an example, you have 600 NOK. How much do you need in order to get 1000 NOK? In this context some [students] will use the 'ten-friends' [i.e. $9+1,8+2$, etc.] in order to come to their answer. 6 has 4 as the ten-friend, and you are missing 400 NOK. Other [students] know +/- are inverse functions. They will use $1000-600=400,600+400=1000$ or $1000-400=600$.
\end{abstract}

In this example extract from teacher $\mathrm{D}$, application of knowledge in new contexts is highlighted. This is an important aspect of problem solving in classrooms, giving students opportunities to explore problems and come up with their own strategies (Bjuland \& Jaworski, 2009; Schoenfeld, 2007). From this teacher's written discourse, it is also visible that the students' previous knowledge is seen as a prerequisite for being able to apply knowledge in new contexts (e.g. NOU 2015:8; Sawyer, 2014).

\title{
Challenges and "Success Stories" in Teaching for Deep Learning
}

When describing what they as teachers find challenging when planning and carrying out teaching which promotes students' deep learning, the analyses of teachers' written discourses reveal that ten out of the eleven teachers characterise the challenges by being alone as a teacher with a (too big) group of students. As an example, teacher A writes the following: "Resources - much [time] alone with 28 students - 28 small members of society who should be taken care of and given teaching/learning adapted to their own needs." These teachers' discourses reveal that the relation between one teacher and from 25 to 30 students makes it difficult to "work closely with each individual student" (teacher E) and to include all students (in e.g. classroom discussions and in individual work on tasks). Teacher E, highlighting to work closely with individual students, might be seen 
as different from Fullan's (2013) suggestion that deep learing depends on team work and on the students' learning from and contributing to the learning of others. Five out of the eleven teachers write that it is challenging to plan and to carry out teaching promoting deep learning for the students due to lack of resources such as concrete materials. Three teachers stress the number of mathematical themes to cover as a challenge, exemplified with an extract from teacher B's text:

What is challenging is that many of the school subjects are comprehensive. And then, it becomes a challenge to arrange/adjust deep learning and good progression for students' learning. Some [of the syllabus] must be taught as surface learning, while what is more important [of the syllabus] must be taught for deep learning.

Two teachers' discourses characterise the challenges in relation to the difficulties of using students' mathematical thinking as a resource in their teaching:

To exploit that the students can learn from each other, and establish a good learning community - that it isn't embarrassing to "provide a wrong answer", but on the contrary, it promotes learning. That's also challenging, but it is a goal to unveil and 'exploit' that the students are thinking in [many] incredibly different ways - if one gets to know how other [students] think, this is a way to promote understanding. (teacher $G$ )

Two other teachers place the responsibility on the students being unfocused or restless:

All teaching depends on that the students are focused and kept up when I teach. I often hear from students when I have finished my teaching 'what should I do?' Deep learning is then for the motivated students. Further explanations to students who are not focused will then be 'just do like this'. (teacher I)

The second last challenge which is put forward by two of the teachers is related to the parents. As an example, teacher $\mathrm{F}$ finds it challenging to "make parents realise the importance of their own engagement [...]" Lastly, the same teacher (teacher F) characterises challenges in relation to the teachers' own commitment to mathematics and to the opportunity to discuss with and learn from colleagues (cf. Fullan, 2013; Fullan \& Langworthy, 2014). This last aspect, highlighted by teacher F only, relates to Tchoshanov's (2011) findings that teacher knowledge matters for students' deep learning. In addition to teacher knowledge, teaching practices enhancing student deep learning of complex ideas and performances are crucial for the work of teaching for deep learning (cf. Grossman et al., 2009; Lampert et al., 2010; Zeichner, 2012). Learning from colleagues (teacher F) might relate to learning such teaching practices.

Analyses of teachers' written discourses about what they as teachers succeed in when planning and carrying out teaching which promotes students' deep learning, reveal that "success stories" relate to the same issues as those characterising deep learning (i.e. the codes presented in Table 2). In addition to the characterisations of deep learning (Table 2), two new aspects were visible in one teacher's (teacher F) text: Collaboration with colleagues and the teachers' involvement in mathematics teaching.

\section{CONCLUSION}

In this study, we have investigated a group of Norwegian mathematics teachers' characterisations of deep learning from studying their written discourses. A key finding from our study is that these teachers' conceptualisations of deep learning deal with more than students' development of understanding of concepts and their ability to reflect about their own learning (e.g. NOU 2015:8). Rather than conceptualising deep learning from a student perspective (Sawyer, 2014) or a teacher perspective in isolation, we have found that deep learning in these teachers' views is characterised by the dynamics between two categories: the students' deep learning and the work of teaching for deep learning (e.g. Fullan, 2013).

From our analysis of mathematics teachers' written discourses, we find that the teachers conceptualise deep learning in terms of the following two broad categories: students' deep learning (e.g. Sawyer, 2014, Table 1) and the work of teaching for deep learning (e.g. Fullan \& Langworthy, 2014). In both categories, the following aspects are highlighted: students' previous knowledge or background knowledge, students' thinking and their (relational) understanding, interdisciplinarity and relations to daily life. Related to the work of teaching for deep learning, variation in mediating tools, variation in approaches to teaching, the learning 
objective for a lesson and the importance of applying knowledge are the conceptualisations put forward in the teachers' written texts (see Table 2).

Analyses of the teachers' written discourses on what they think they succeed in when planning and carrying out teaching which promotes students' deep learning, reveal that their discourses on 'success stories' relate to the same issues as those characterising deep learning (i.e. the codes presented in Table 2, first column). In addition to the characterisations of deep learning, collaboration with colleagues and the teachers' involvement in mathematics teaching is highlighted, but by one teacher only.

When the teachers write about what they as teachers find challenging when planning and carrying out teaching which promotes students' deep learning, our analyses reveal that most of the teachers characterise the main challenge as being alone with a group of students which is too big. Some teachers' discourses reveal that challenges relate to lack of resources, too many mathematical themes, and to the difficulties of using students' mathematical thinking as a resource in teaching. Two teachers place the responsibility for teaching for deep learning on the students. Another reason put forward by these two teachers are parents not being engaged. Only one teacher characterises challenges in relation to the teacher's own commitment to mathematics and to the opportunity to discuss with and learn from colleagues (cf. Fullan, 2013; Fullan \& Langworthy, 2014). This is interesting, since teachers' knowledge (cf. Tchoshanov, 2011) as well as teaching practices (e.g. Lampert et al., 2010) are found to be important in order for students to learn deeply. This is also interesting seen in relation to the point of departure for the written texts analysed for the purpose of this study: A collaborative research and development project where teacher educators/researchers, teachers and school leaders work together in order to develop the students' opportunities for developing "deeper knowledge" (Sawyer, 2014, p. 14).

As a pedagogical implication from this study, we suggest that it is of importance for in-service teachers (in the project this study is a part of as well as similar projects worldwide) to be conscious about their own characterisations of deep learning as well as their characterisations of ambitious teaching practices (Lambert et al., 2010) essential for the work of teaching enhancing students' deep learning. Ambitious teaching practices are used in instructional dialogues in which teachers and their students can engage with each other and share ideas and elaborate on different points of view (Alexander, 2008), drawing on important attributes of a classroom learning environment that promotes learning outcomes i.e. that lessons need to be learner centered, knowledge centered, and community centered (Bransford et al., 2000/2004). A second pedagogical implication relates to the concept of deep learning. We suggest that this is given attention by being discussed with teachers (cf. the different concepts used to capture deep learning as a product as well as a process). Fullan's (2013) C's characterising deep learning (e.g. communication, collaboration and critical thinking and problem solving) might be a point of departure for such a discussion.

An implication for future research would be to study aspects of deep learning as constructed in written discourses from other groups than the group of (Norwegian) mathematics teachers, including challenges and 'success stories' related to teaching promoting deep learning visible in these teachers' written discourses. A second implication would be to study mathematics teachers' discourses about deep learning as constructed in oral and written discourses as well as oral and written discourses from teachers from other subjects than mathematics. Adding oral data from e.g. interviews would make it possible to ask follow-up questions in order to let the teachers justify or deepen their answers to the questions asked (see Table 2). Since some of the methods used by the teachers (e.g. "use multiplication in practical situations" (teacher E) and using "elbow partner" (teacher K)) could just as well lead to surface learning if it is just a routine (talking to someone else does not necessarily lead to deep learning; it depends on what they are talking about), an interview would be a context where teachers' responses could be elaborated upon.

Based on the fact that the present study only provides a glimpse into a few mathematics teachers' discourses, we call for longitudinal studies researching the development of teachers' characterisations of deep learning over time. Longitudinal studies across subjects will make it possible for the research community to develop a more comprehensive understanding of teachers' characterisations of deep learning as well as if and how their characterisations develop over time.

\section{Disclosure statement}

No potential conflict of interest was reported by the authors. 


\section{Notes on contributors}

Janne Fauskanger - Department of Education and Sports Science, University of Stavanger, Stavanger, Norway.

Raymond Bjuland - Department of Education and Sports Science, University of Stavanger, Stavanger, Norway.

\section{REFERENCES}

Alexander, R. (2008). Towards dialogic teaching: rethinking classroom talk (4 $4^{\text {th }}$ Ed.). York: Dialogos.

Bjuland, R., \& Jaworski, B. (2009). Teachers' perspectives on collaboration with didacticians to create an inquiry community. Research in Mathematics Education, 11(1), 21-38. https://doi.org/10.1080/14794800902732209

Bransford, J. D, Brown, A. L, \& Cocking, R. R. (2000/2004) (Expanded Edition). How people learn: Brain, mind, experience, and school. Washington, DC: National Academic Press.

Byrne, M., Flood, B., \& Willis, P. (2004). Validation of the approaches and study skills inventory for students (assist) using accounting students in the USA and Ireland: a research note. Accounting Education, 13(4), 449-459. https://doi.org/10.1080/0963928042000306792

Dahlin, B., \& Watkins, D. (2000). The role of repetition in the processes of memorizing and understanding: A comparison of the views of German and Chinese secondary school students in Hong Kong. British Journal of Educational Psychology, 70, 65-84. https://doi.org/10.1348/000709900157976

de Jong, T., \& Ferguson-Hessler, M. (1996). Types and qualities of knowledge. Educational Psychologist, 31(2), 105-113. https://doi.org/10.1207/s15326985ep3102_2

Fan, L., \& Bokhove, C. (2014). Rethinking the role of algorithms in school mathematics: a conceptual model with focus on cognitive development. ZDM - The International Journal on Mathematics Education, 46(3), 481-492. https://doi.org/10.1007/s11858-014-0590-2

Fauskanger, J., \& Mosvold, R. (2014). Innholdsanalysens muligheter i utdanningsforskning. [The affordances of content analysis in educational research]. Norsk Pedagogisk Tidsskrift, 98(2), 127-139.

Fullan, M. (2013). Great to excellent: Launching the next stage of Ontario's education agenda. Retrieved from http://www.michaelfullan.ca/wp-content/uploads/2013/09/13_Fullan_Great-to-Excellent.pdf

Fullan, M., \& Langworthy, M. (2014). A rich seam: How new pedagogies find deep learning. London: Pearson.

Grossman, P., Compton, C., Igra, D., Ronfeldt, M., Shahan, E., \& Williamson, P. (2009). Teaching practice: A cross-professional perspective. Teachers College Record, 111(9), 2055-2100.

Hemmi, K., \& Ryve, A. (2015). Effective mathematics teaching in Finnish and Swedish teacher education discourses. Journal of Mathematics Teacher Education, 18, 501-521. https://doi.org/10.1007/s10857014-9293-4

Hiebert, J., \& Carpenter, T. P. (1992). Learning and teaching with understanding. In D. A. Grouws (Ed.), Handbook of research on mathematics teaching and learning: A project of the National Council of Teachers of Mathematics (pp. 65-97). New York, NY: Macmillan Publishing Co, Inc.

Hiebert, J., \& Lefevre, P. (1986). Conceptual and procedural knowledge in mathematics: An introductory analysis. In J. Hiebert (Ed.), Conceptual and procedural knowledge: The case of mathematics (pp. 127). Hillsdale, NJ: Erlbaum.

Hsieh, H. -F., \& Shannon, S. E. (2005). Three approaches to qualitative content analysis. Qualitative Health Research, 15(9), 1277-1288. https://doi.org/10.1177/1049732305276687

Lampert, M., Beasley, H., Ghousseini, H., Kazemi, E., \& Franke, M. (2010). Using designed instructional activities to enable novices to manage ambitious mathematics teaching. In M. K. Stein \& L. Kucan (Eds.), Instructional explanations in the disciplines (pp. 129-141). New York, NY: Springer. https://doi.org/10.1007/978-1-4419-0594-9_9

Leung, F. K. S. (2006). Mathematics education in East Asia and the West: does culture matter? In F. K. S. Leung, K.-D. Graf \& F. J. Lopez-Real (Eds.), Mathematics education in different cultural traditions: A comparative study of East Asia and the West (pp. 21-46). New York: Springer. https://doi.org/10.1007/0387-29723-5_1

Li, S. (1999). Does practice make perfect? For the Learning of Mathematics, 19(3), 33-35. 
Marton, F. (1975). On non-verbatim learning 1. level of processing and level of outcome. Scandinavian Journal of Psychology, 16(1), 273-279. https://doi.org/10.1111/j.1467-9450.1975.tb00193.x

Marton, F., \& Säljö, R. (1976). On qualitative differences in learning: I-Outcome and process. British Journal of Educational Psychology, 46(1), 4-11. https://doi.org/10.1111/j.2044-8279.1976.tb02980.x

Marton, F., Dall'Alba, G., \& Tse, K. -T. (1996). Memorising and understanding: the keys to the paradox? In D. Watkins \& J. B. Biggs (Eds.), The Chinese learner: Cultural, psychological, and contextual influences (pp. 69-83). Hong Kong: Comparative Education Research Centre; and Melbourne: Australian Council for Educational Research.

NOU (2015:8). Fremtidens skole. Fornyelse av fag og kompetanser [The school for the future. The renewal of subjects and competences]. Oslo: Kunnskapsdepartementet.

Rillero, P. (2016). Deep conceptual learning in science and mathematics: Perspectives of teachers and administrators. Electronic Journal of Science Education, 20(2), 14-31.

Rittle-Johnson, B., \& Siegler, R. S. (1998). The relation between conceptual and procedural knowledge in learning mathematics: A review. In C. Donlan (Ed.), The development of mathematical skill (pp. 75110). Hove, UK: Psychology Press.

Rittle-Johnson, B., Siegler, R. S., \& Alibali, M. W. (2001). Developing conceptual understanding and procedural skill in mathematics: An iterative process. Journal of Educational Psychology, 93(2), 346362. https://doi.org/10.1037/0022-0663.93.2.346

Sawyer, R. K. (2014, Eds.). The Cambridge handbook of the learning sciences. Cambridge: Cambridge University Press.

Schoenfeld, A. H. (2007). Problem solving in the United States, 1970-2008: Research and theory, practice and politics. ZDM - The International Journal on Mathematics Education, 39(5-6), 537-551. https://doi.org/10.1007/s11858-007-0038-z

Skemp, R. R. (1976). Relational understanding and instrumental understanding. Mathematics Teaching, 77, 20-26.

Star, J. R. (2005). Reconceptualizing procedural knowledge. Journal for Research in Mathematics Education, $36(5), 404-411$.

Tchoshanov, M. A. (2011). Relationship between teacher knowledge of concepts and connections, teaching practice, and student achievement in middle grades mathematics. Educational Studies in Mathematics, 76(2), 141-164. https://doi.org/10.1007/s10649-010-9269-y

Zeichner, K. (2012). The turn once again toward practice-based teacher education. Journal of Teacher Education, 63(5), 376-382. https://doi.org/10.1177/0022487112445789 